\title{
Performance Evaluation of Micro Sprinkler System
}

\author{
Surve Aishwarya Pradeep, Dhamane Shweta Govind, \\ Jagdale Kiran Dharmaraj and Khambe Ankita Suresh
}

\author{
Dr. BudhajiraoMulik College of Agricultural Engineering and Technology, Mandki-Palvan, \\ Maharashtra, India \\ *Corresponding author
}

\section{A B S T R A C T}

K e y w o r d s
Distribution,
Efficiency, Micro
sprinkler, Operating
pressure,
Uniformity
coefficient

Keywords

Distribution Efficiency, Micro pressure, Uniformity coefficient

\section{Introduction}

Agriculture is the backbone of Indian economy and water is the most essential single input required for increasing the agricultural production. In India irrigation resources are limited and the water use efficiency of conventional method of irrigation is very low, resulting in low agricultural productivity. Therefore, judicious use of water is key input in agriculture development (Michael, 2008). The modern systems of irrigation like drip, sprinkler coupled with improved water management practices enhance the water use efficiency and productivity. In the sprinkler method of irrigation, water is sprayed into the air and allowed to fall on the ground surface somewhat resembling rainfall. It saves about 50 per cent of water compared to surface method and increases the productivity by 15 to 25 percent (Mane and Ayare, 2011). Micro sprinkler is suitable for all crops except jute and rice as these crops requires standing 
water. It is adaptable for almost all types of soil but it is best suited to sandy loam soil and undulating topography (Mane and Ayare, 2011). Uniform water distribution from micro sprinkler is necessary to maximize crop production and to improve quality of produce. Micro sprinkler irrigation system operates at low pressure, so power requirement is less.

The performance of the micro sprinklers depends upon the uniformity, operating pressure of the system as well as the micro sprinkler arrangement (height and spacing). The performance of emission device used will have a major impact on success of the system. It was therefore felt necessary to test the micro-sprinkler at suitable operating pressure and riser height, so that designer can select the best suitable micro-sprinkler for a specific requirement and system can be designed accordingly. Keeping all this in view, field experiments were conducted to evaluate the micro sprinkler at varying operating pressure and riser height.

This study investigated the effect of operating pressure and wind velocity on the distribution pattern of micro sprinkler irrigation system. Further this study is intended for guiding the best suitable arrangement of micro sprinkler.

\section{Materials and Methods}

Field experiments were conducted for studying performance of micro sprinkler at farm of Dr. BMCAET Mandki-Palvan. The micro-sprinkler selected for the performance evaluation test was having discharge $85 \mathrm{lph}$. The performance evaluation of micro sprinkler was carried out for 2 riser height such as $1 \mathrm{~m}$ and $1.5 \mathrm{~m}$ at different operating pressure such as 1.5 and $2 \mathrm{~kg} / \mathrm{cm}^{2}$ and the wind velocity were also recorded during the test run and treatments were as follows as shown in Table 1
The determination of uniformity coefficient, distribution uniformity and average application depth was done using two arrangement methods such as linear arrangement and point arrangement as shown in fig 1 and 2.

For point arrangement a single micro sprinkler and for linear arrangement two micro sprinklers were placed in a line with suitable spacing. After placing the micro sprinklers the grids were plotted on the field and the catch cans were arranged on grid pattern to collect the precipitation. The precipitation of the micro sprinkler was collected using graduated cylinder and required observations were noted for further analysis.

Uniformity coefficient (UC) was determined by Christiansen's formula (Michael, 1978) as given in equation 1 . The ASAE recommended classification of uniformity coefficient of micro sprinkler is shown in table 2 .

Uniformity coefficient $\left(\right.$ UC) $={ }^{\left(1-\frac{\Sigma x}{m n}\right) \times 100} 1$.

Where,

$\Sigma X=$ Sum of absolute deviation of individual observation.

$\mathrm{m}=$ Average of all observations

$\mathrm{n}=$ Number of observations

The distribution uniformity (DU) indicates the uniformity of application of irrigation water throughout the field and was computed by equation 2 given by Merrian and Keller (1978)

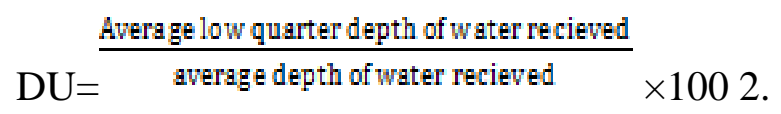

Where, 
$\mathrm{DU}=$ Distribution uniformity of micro sprinkler, percent

General Criteria for acceptability ratings of distribution uniformities, based on guidelines for center pivot irrigators (Irrigation Evaluation Code of Practice, 2010)as reported in Table 3 were used in the study.

The average application depth was calculated by using Boman method by equation 3 , (Boman, 1988).

Average application depth $\quad(\mathrm{mm} / \mathrm{hr})$
$=\frac{\text { Sum of depth collected in catch can }}{\text { Total number of catch can }} 3$.

The discharge was calculated by using the following equation 4 .

Discharge $=\frac{\text { Volume of Water Collected (lit) }}{\text { Time of Filling (min) }} 4$.

\section{Results and Discussion}

The experimental findings for point and linear arrangement of micro sprinkler are tabulated and the values of average values of UC and
DU, average application depth, and sprinkler discharge are presented in table in appendix section respectively. It was observed for the micro sprinkler when operated for riser height $1 \mathrm{~m}$ placed at point arrangement, the value of average uniformity coefficient for micro sprinkler was found maximum i.e $78.68 \%$ at operating pressure $2 \mathrm{~kg} / \mathrm{cm}^{2}$ and riser height $1 \mathrm{~m}$ at wind speed of $1.7 \mathrm{~km} / \mathrm{hr}$. When operated at riser height $1.5 \mathrm{~m}$ and placed at point arrangement it was found that value of average uniformity coefficient for micro sprinkler was found maximum i.e $82.97 \%$ at operating pressure $1.5 \mathrm{~kg} / \mathrm{cm}^{2}$ and riser height $1 \mathrm{~m}$ at wind speed of $1.46 \mathrm{~km} / \mathrm{hr}$. It is interred that for point arrangement, the uniformity coefficient decreased as the wind speed increased. While for linear arrangement the micro sprinkler was initially operated at $1 \mathrm{~m}$ the uniformity coefficient was found to be maximum i.e., $72.27 \%$ at operating pressure $2 \mathrm{~kg} / \mathrm{cm}^{2}$ and riser height $1 \mathrm{~m}$ at wind speed of $1.43 \mathrm{~km} / \mathrm{hr}$. Again, the micro sprinkler was placed at riser height of $1.5 \mathrm{~m}$, the maximum value i.e., $75.60 \%$ at operating pressure 2 $\mathrm{kg} / \mathrm{cm}^{2}$ and riser height $1.5 \mathrm{~m}$ at wind speed of $1.43 \mathrm{~km} / \mathrm{hr}$.

Table.1 Treatments used in this study for evaluating the performance of micro sprinkler

\begin{tabular}{|l|c|c|c|c|}
\hline Treatment & T1 & T2 & T3 & T4 \\
\hline Riser height $(\mathbf{m})$ & 1 & 1 & 1.5 & 1.5 \\
\hline Operating pressure $\left(\mathbf{k g} / \mathbf{c m}^{2}\right)$ & 1.5 & 2 & 1.5 & 2 \\
\hline
\end{tabular}

Table.2 ASAE (1996) Recommended Classification of Uniformity coefficient

\begin{tabular}{|c|c|c|}
\hline Sr.No & Uniformity coefficient, $\%$ & Classification \\
\hline $\mathbf{1}$ & Above $90 \%$ & Excellent \\
\hline $\mathbf{2}$ & $90 \%-80 \%$ & Good \\
\hline $\mathbf{3}$ & $80 \%-70 \%$ & Fair \\
\hline $\mathbf{4}$ & $70 \%-60 \%$ & Poor \\
\hline $\mathbf{5}$ & Below $60 \%$ & Unacceptable \\
\hline
\end{tabular}


Table.3 ASAE (1996) Recommended Classification of Distribution Uniformity

\begin{tabular}{|c|c|c|}
\hline Sr. No. & Classification & Distribution Uniformity \% \\
\hline $\mathbf{1}$ & Excellent & $>94$ \\
\hline $\mathbf{2}$ & Very Good & 93 to 87 \\
\hline $\mathbf{3}$ & Good & 86 to 75 \\
\hline $\mathbf{4}$ & Fair & 74 to 62 \\
\hline $\mathbf{5}$ & Poor & 61 to 50 \\
\hline $\mathbf{6}$ & Unacceptable & $<50$ \\
\hline
\end{tabular}

Appendix

Average values of UC (\%), DU (\%) and Average application depth, (mm/hr)

\begin{tabular}{|c|c|c|c|c|c|}
\hline Arrangement & Treatment & $\begin{array}{l}\text { Wind } \\
\text { speed, } \\
\mathbf{k m} / \mathbf{h r}\end{array}$ & $\mathrm{UC}, \%$ & DU, & $\begin{array}{l}\text { Average application } \\
\text { depth, } \mathrm{mm} / \mathrm{hr}\end{array}$ \\
\hline \multirow[t]{8}{*}{ Point } & \multirow[t]{2}{*}{$\mathrm{T} 1$} & 1.8 & 80.33 & 74.76 & 1.8 \\
\hline & & 2.28 & 73.33 & 70.13 & 2.23 \\
\hline & \multirow[t]{2}{*}{$\mathrm{T} 2$} & 1.7 & 77.48 & 76.83 & 1.86 \\
\hline & & 3.48 & 70.09 & 63.14 & 2.28 \\
\hline & \multirow[t]{2}{*}{$\mathrm{T} 3$} & 1.46 & 82.97 & 71.4 & 1.7 \\
\hline & & 1.5 & 80.95 & 79.23 & 1.74 \\
\hline & \multirow[t]{2}{*}{$\mathrm{T} 4$} & 1.6 & 78.68 & 75.8 & 2.12 \\
\hline & & 1.9 & 68.3 & 46.78 & 2.17 \\
\hline \multirow[t]{8}{*}{ Linear } & \multirow[t]{2}{*}{$\mathrm{T} 1$} & 1.56 & 72.19 & 60.6 & 3.2 \\
\hline & & 1.6 & 71.82 & 58.62 & 3.4 \\
\hline & \multirow[t]{2}{*}{$\mathrm{T} 2$} & 1.5 & 72.27 & 68.61 & 3.6 \\
\hline & & 1.93 & 68.25 & 54.71 & 3.9 \\
\hline & \multirow[t]{2}{*}{$\mathrm{T} 3$} & 1.53 & 73.34 & 50.59 & 3.94 \\
\hline & & 1.7 & 73.29 & 50.24 & 3.8 \\
\hline & \multirow[t]{2}{*}{$\mathrm{T} 4$} & 1.43 & 75.6 & 64.56 & 2.9 \\
\hline & & 1.46 & 71.78 & 56.41 & 3.4 \\
\hline
\end{tabular}

Average discharge (lph) of micro sprinkler at various operating pressure $\left(\mathrm{kg} / \mathrm{cm}^{2}\right)$

\begin{tabular}{|c|c|}
\hline Operating pressure, $\mathbf{~} \mathbf{k g} / \mathbf{c m}^{\mathbf{2}}$ & Discharge of micro sprinkler, Iph \\
\hline $\mathbf{1 . 5}$ & 79.5 \\
\hline $\mathbf{2}$ & 94.5 \\
\hline
\end{tabular}


Fig.1 Point arrangement of micro sprinkler

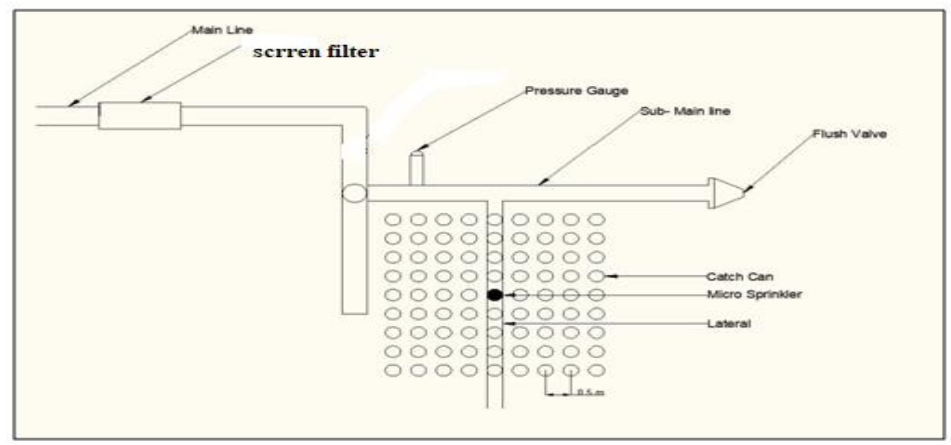

Fig.2 Linear arrangement

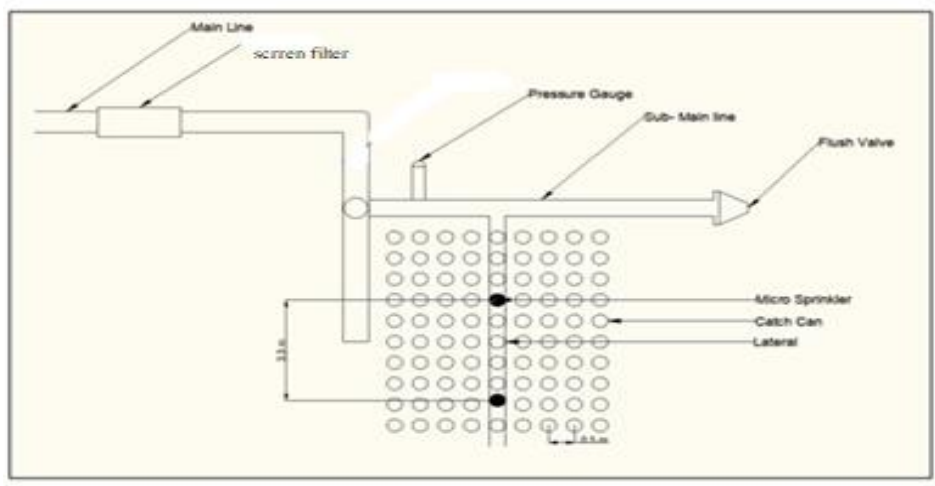

It is also observed that the value of average distribution uniformity for micro sprinkler was found maximum i.e., $96.83 \%$ at operating pressure $2 \mathrm{~kg} / \mathrm{cm} 2$ and riser height $1 \mathrm{~m}$ at wind speed $1.7 \mathrm{~km} / \mathrm{hr}$ at $1 \mathrm{~m}$ height in point arrangement. Further when the height increased to $1.5 \mathrm{~m}$ the we can observe that the value of average distribution uniformity for micro sprinkler was found maximum i.e., $79.23 \%$ at operating pressure $1.5 \mathrm{~kg} / \mathrm{cm}^{2}$ and at wind speed $1.46 \mathrm{~km} / \mathrm{hr}$. The distribution is affected by wind speed. At greater wind velocity the value of distribution uniformity is lower. While for linear arrangement we can observe that the value of average distribution uniformity for micro sprinkler was found maximum i.e., $68.61 \%$ at operating pressure $2 \mathrm{~kg} / \mathrm{cm}^{2}$ and riser height $1 \mathrm{~m}$ at wind speed $1.5 \mathrm{~km} / \mathrm{hr}$. Further, we can observe that the value of average distribution uniformity for micro sprinkler was found maximum i.e., $64.56 \%$ at operating pressure $2 \mathrm{~kg} / \mathrm{cm}^{2}$ and riser height $1.5 \mathrm{~m}$.

In Point arrangement system, the maximum application depth i.e $2.28 \mathrm{~mm} / \mathrm{hr}$ obtained at the operating pressure $2 \mathrm{~kg} / \mathrm{cm}^{2}$ and riser height $1 \mathrm{~m}$. While in linear arrangement, the maximum application depth i.e., $3.94 \mathrm{~mm} / \mathrm{hr}$ obtained at the operating pressure $1.5 \mathrm{~kg} / \mathrm{cm}^{2}$ and riser height $1.5 \mathrm{~m}$.

The micro sprinkler discharge increase as the operating pressure increases. The maximum discharge obtained at the operating pressure 2 $\mathrm{kg} / \mathrm{cm}^{2}$.

In conclusion the micro sprinkler was found to have maximum uniformity coefficient when placed at point arrangement rather than 
linear arrangement. The uniformity was greatly affected by the wind velocity. Higher wind velocities lowered the uniform distribution of water. As the pressure of the system increased the uniformity coefficient was found to get increased. The pressure of the system also had a positive effect on the sprinkler discharge. At higher operating pressure, greater discharge was observed. At greater operating pressures the finer drop size were observed emitting out of the micro sprinkler. It had a positive relation with the average application depth. The value of average application depth was found to be greater at $1 \mathrm{~m}$ than $1.5 \mathrm{~m}$ riser height. According to the ASAE classification standards the micro sprinkler lies under fair to good class and that is acceptable.

\section{References}

Michael A.M. (2008). Irrigation Theory and Practice. Vikas Publishing House Pvt.
Ltd. New Delhi.

Mane M.S. and B.L. Ayare.(2011). Principles of Sprinkler Irrigation. Vol. II, Jain Brothers, New Delhi.P 524

Michael A. M. (1978).Irrigation Theory and Practice. Vikas Publishing House Pvt. Ltd. New Delhi.

ASAE. (1996). Field Evaluation of Micro Irrigation System. EP405.1. ASAE Standards. Amer. Soc. Agric. Engr., St.Joseph, MI. Pp. 756-759.

Merrian J. L. and J. Keller. (1978). Farm Irrigation System Evaluation. A Guide to Management. Utah State University, Logan, Utah.

Irrigation Evaluation Code of Practice. (2010). Sustainable Farming Project 02051.2005, New Zealand.

Boman B. J. (1998). Distribution Pattern of Micro Sprinkler and Spray Emitter. Applied Agriculture, 5(1): 50-65

\section{How to cite this article:}

Surve Aishwarya Pradeep, Dhamane Shweta Govind, Jagdale Kiran Dharmaraj and Khambe Ankita Suresh. 2021. Performance Evaluation of Micro Sprinkler System. Int.J.Curr.Microbiol.App.Sci. 10(01): 1630-1635. doi: https://doi.org/10.20546/ijcmas.2021.1001.190 